\title{
SARS-CoV-2 infects and replicates in photoreceptor and retinal ganglion cells of human retinal organoids
}

Yotam Menuchin-Lasowski*,1, André Schreiber ${ }^{*}, 2$, Aarón Lecanda ${ }^{1}$, Angeles MecateZambrano $^{2}$, Linda Brunotte ${ }^{2}$, Olympia E. Psathaki ${ }^{1,3}$, Stephan Ludwig ${ }^{2}$, Thomas Rauen*,1, Hans R. Schöler ${ }^{\#, 1,4}$.

${ }^{1}$ Department for Cell and Developmental Biology, Max Planck Institute for Molecular Biomedicine, Röntgenstrasse 20, 48149 Münster, Germany.

${ }^{2}$ Institute of Virology Münster, Westfaelische Wilhelms University, Münster, Germany.

${ }^{3}$ Department of biology and center of cellular nanoanalytics (CellNanOs), University of Osnabrück, Barbarastrasse 11, 49076 Osnabrück, Germany

${ }^{4}$ Medical Faculty, Westfaelische Wilhelms University, Domagkstrasse 3, 48449 Münster, Germany.

*These authors contributed equally to the study

\#Corresponding authors. Contact information: thomas.rauen@mpi-muenster.mpg.de, office@mpimuenster.mpg.de.

\section{Abstract:}

Several studies have pointed to retinal involvement in COVID-19 disease, yet many questions remain regarding the ability of SARS-CoV-2 to infect and replicate in retinal cells and its effects on the retina. Here we have used human stem cell-derived retinal organoids to study retinal infection by the SARS-CoV-2 virus. Indeed, SARS-CoV-2 can infect and replicate in retinal organoids, as it is shown to infect different retinal lineages, such as retinal ganglion cells and photoreceptors. SARS-CoV-2 infection of retinal organoids also induces the expression of several inflammatory genes, such as interleukin 33, a gene associated with acute COVID-19 disease and retinal degeneration. Finally, we show that the use of antibodies to block the ACE2 receptor significantly reduces SARS-CoV-2 infection of retinal organoids, indicating that SARS-CoV-2 infects retinal cells in an ACE2-dependent manner. These results suggest a retinal involvement in COVID-19 and emphasize the need to monitor retinal pathologies as potential sequelae of "long COVID”. 


\section{Introduction}

The coronavirus disease 2019 (COVID-19), caused by the severe acute respiratory syndrome coronavirus 2 (SARS-CoV-2), is a global pandemic that is responsible for millions of fatalities. While mild-to-severe respiratory symptoms are most commonly associated with the disease (Huang et al., 2020), neurological (Asadi-Pooya and Simani, 2020; Mao et al., 2020) and ocular (Wu et al., 2020) symptoms have also been described in patients.

Growing evidence suggests retinal involvement in some cases of COVID-19. Different reports identified SARS-CoV-2 RNA in retinal and optic nerve biopsies taken from deceased COVID19 patients (Casagrande et al., 2020; Casagrande et al., 2021), while different retinal anomalies were also identified in patients (Burgos-Blasco et al., 2020; Conrady et al., 2021; Marinho et al., 2020; Pereira et al., 2020; Rodriguez-Rodriguez et al., 2021; Virgo and Mohamed, 2020). Yet, retinal involvement in COVID-19 remains a controversial topic, as other studies were not able to detect retinal pathologies in patients (Pirraglia et al., 2020). Furthermore, one study reported failure to isolate virus from SARS-CoV-2 RNA-positive retinal biopsies and an inability to detect any SARS-CoV-2 spike protein from those biopsies by immunohistochemical analysis, leading investigators to suggest that SARS-CoV-2 can infect but not actively replicate in retinal cells (Casagrande et al., 2021). It also remains unclear which retinal structures are infected by SARS-CoV-2 and whether the retinal anomalies reported are due to retinal infection or systemic organ dysfunction (Casagrande et al., 2020; de Figueiredo et al., 2020).

Organoids are three-dimensional, tissue cultures that resemble specific organs in their morphology, cell-type composition, or function. Different research groups have used organoids generated from human stem cells to study the infection of SARS-CoV-2 in the context of different organs (Lamers et al., 2020; Monteil et al., 2020; Pellegrini et al., 2020; Ramani et al., 2020; Zhang et al., 2020). Such studies have demonstrated that SARS-CoV-2 can infect 
neurons and neural progenitors (Ramani et al., 2020; Zhang et al., 2020). Retinal organoids are among the most physiologically accurate neural organoid models, as they contain all the major retinal cell types, follow a developmental trajectory similar to that of the human retina in vivo, and are correctly organized in a typical layered structure (Achberger et al., 2019; Nakano et al., 2012; Zhong et al., 2014).

Here we use retinal organoids to show that SARS-CoV-2 can infect retinal cells, mainly retinal ganglion cells (RGCs) but also photoreceptors, as well as replicate in them. Moreover, retinal SARS-CoV-2 infection induces the expression of several inflammatory genes and is reduced by treatment of the organoids with an anti-ACE-2 antibody.

\section{Results}

\section{SARS-CoV-2 infects retinal organoids and replicates in retinal cells}

To generate retinal organoids in large quantities we have combined different widely used protocols (Capowski et al., 2019; Kuwahara et al., 2015; Zhong et al., 2014). The organoids generated followed correct retinal development and contained a thick layer of VSX2+ retinal progenitors and a basal layer of differentiated PAX6+/VSX2- RGC and amacrine cells by day 50 into the protocol (Figure 1A). At later stages, the organoids had gained a layered retinal structure with an inner nuclear layer (INL), containing the different INL cell types such as OTX2+ bipolar cells, AP2A+ amacrine and horizontal cells, and CRALBP+ Müller glia, separated from an outer nuclear layer (ONL), containing OTX2+ photoreceptors (Figure 1B). The photoreceptor cells expressed rod and cone opsins concentrated in outer segment-like structures (Figure 1C), indicating highly mature organoids.

To test the ability of SARS-CoV-2 to infect retinal cells, relatively mature human retinal organoids (day of differentiation $\geq 125$ ) were treated with SARS-CoV-2 and then incubated for different incubation periods. The infected organoids were then analyzed by different 
methods to assess SARS-CoV-2 infection and replication. SARS-CoV-2 RNA was detected by qPCR analysis in SARS-CoV-2-treated organoids but not in the controls (Figure 1D), suggesting that the treated organoids were indeed infected with SARS-CoV-2. Furthermore, a viral plaque assay was used to measure the active viral concentrations produced by the infected organoids after different incubation times. The appearance of viral plaques in the cell cultures treated with supernatant that was incubated for 24 hours with the infected organoids indicated that new virus progeny was being generated, providing the first evidence that SARS-CoV-2 replicates within human retinal tissue. Accordingly, virus titers were increased after 48 hours of incubation with the infected organoids but surprisingly were reduced back to levels which are similar to the 24 -hour time point after 72 hours. A similar phenomenon was reported in SARS-CoV-2-infected brain organoids (Zhang et al., 2020).

Finally, an immunofluorescence analysis identified a small number of SARS-CoV-2 nucleocapsid protein $(\mathrm{N})$ positive cells in SARS-CoV-2-treated organoids on days 130 and 160 of differentiation (Figure $1 \mathrm{~F}$ and $\mathrm{G}$ ) but not in controls (Figure 2F). Interestingly, many of the $\mathrm{N}+$ cells were found in the ONL of the organoid and some exhibited a typical photoreceptor morphology (Figure 1G). While most of the work presented here was made using human induced pluripotent stem cells (hiPSCs), organoids derived from human embryonic stem cells were also found to be permissive to infection (Figure S1A).

The number of $\mathrm{N}+$ cells identified in retinal organoids at these late developmental stages was relatively low (3.8 per organoid, on average, on day 130, Figure 2D). To investigate whether retinal organoids at earlier developmental stages are more susceptible to SARS-CoV-2 infection, we infected less mature retinal organoids, at either day 74 or day 90 , and compared the number of $\mathrm{N}+$ cells with SARS-CoV-2-infected 130-day-old retinal organoids (Figure 2A, $\mathrm{B}$ and $\mathrm{C})$. The number of $\mathrm{N}+$ cells on day 74 -infected retinal organoids was significantly higher than in either day 90-infected or day 130-infected organoids (an average of 22.14 per organoid, 
in contrast to 8.7 for day 90 and 3.8 for day 130). Strikingly, SARS-CoV-2-infected cells appeared to localize to the inner retina in younger retinal organoids whereas they predominantly affected the outer retina in older organoids.

\section{Retinal ganglion cells are particularly susceptible to SARS-CoV-2 infection}

To identify the retinal cells that are infected, day 74 infected organoids were co-immunostained with antibodies directed against SARS-CoV-2 $\mathrm{N}$ and retinal cell type-specific markers (Figure 3A-D). Interestingly, RGCs appeared to be the most commonly infected cell type, as about $40 \%$ of the N+ cells also stained positive for the RGC marker SNCG (Figure 3A and D). A clear yet smaller number of OTX2+ photoreceptors (and perhaps a few bipolar cells) and $\mathrm{AP} 2 \mathrm{~A}+$ amacrine cells (Figure 3B and D) also stained positive for SARS-CoV-2 N, indicating the permissibility of these cells. An even smaller number of VSX2+ progenitors (and perhaps a few bipolar cells) also stained positive for $\mathrm{N}$ (Figure 3C and D), suggesting that progenitor cells can also be infected. As Müller glia cells are still rare at this stage of retinal organoid development, we did not attempt to stain the organoids with a Müller glia marker as well.

ACE2, is the receptor most commonly associated with the SARS-CoV-2 infection pathway. While ACE2 mRNA expression in the human retina is thought to be low, ACE2 protein is present in the human and rat retina (Senanayake et al., 2007; Tikellis et al., 2004). Accordingly, an immunohistochemical analysis identified an ACE2 signal concentrated in OTX2+ photoreceptors and HUC/D+ ganglion and amacrine cells in our retinal organoids (Figure 3E and G). These results are consistent with the retinal infection profile of SARS-CoV-2 shown here.

\section{A transcriptomic analysis of SARS-CoV-2 infected retinal organoids}


To study the effect of SARS-CoV-2 infection on retinal organoids, we conducted an RNA-seq analysis to compare the transcriptome of noninfected retinal organoids to that of retinal organoids that were infected with SARS-CoV-2 on day 80 of differentiation and incubated for either 24 or 96 hours after infection. Unsurprisingly, 10 SARS-CoV-2 gene transcripts were highly enriched within the infected samples, though no difference was seen between 24 hours post-infection incubation and 96 hours post-infection incubation (Figure 4A). This is consistent with the reduction in plaque-forming units (PFU) observed in the plaque assay after 72 hours (Figure 1D).

In accordance with the immunohistochemical analysis, ACE2 transcripts were identified in all of the samples, with no change in expression due to virus infection at either incubation time (Figure 4C), suggesting that the infection of retinal cells does not result in ACE2 upregulation. This result contradicts studies suggesting ACE2 upregulation upon SARS-CoV-2 infection of other types of host cells (Butler et al., 2021).

Next, we compared the transcriptome of all of the infected samples to that of the control samples to identify genes that are differentially expressed (DE) upon infection. This analysis identified 759 DE genes (FDR adjusted P-value $\leq 0.05$ ), of which 366 were upregulated and 393 were downregulated (Figure S1C).

To gain further information regarding the processes occurring in the retinal organoids upon infection, a gene ontology (GO) analysis of the most highly upregulated genes (FDR adjusted P-value $\leq 0.05$, fold change $\geq 2$ ) was performed using the Enrichr software (Chen et al., 2013; Kuleshov et al., 2016). The top five most enriched biological process categories in this analysis were "Potassium ion transport", "Cellular response to cytokine stimulus", "Cellular response to BMP stimulus", "Metal ion transport", and "Cytokine-mediated signaling pathway" (Figure 4B and Table 1). 
The enrichment of cytokine-related genes indicates the mounting of an immune response upon SARS-CoV-2 infection. KEGG pathway analysis performed using Enrichr with the same genes found that SARS-CoV-2 infection also led to the enrichment of genes related to the JAK-STAT signaling pathway, a signaling pathway involved in inflammation and the innate antiviral interferon response (data not shown). The enrichment of potassium ion transport-related genes in the data-set may correspond with evidence suggesting that hypokalemia is a relatively common pathology of COVID-19 (Mabillard and Sayer, 2020).

Comparison of the transcriptome changes of SARS-CoV-2-infected retinal organoids to those of other neural progenitor-derived organoid systems may allow for a better understanding of the unique features of the retinal response to SARS-CoV-2 infection. To this end, we have used a data set of genes altered in choroid plexus organoids upon SARS-CoV-2 infection (Jacob et al., 2020). While the choroid plexus is not a neuronal tissue like the retina, it does develop from neural progenitors of the neural tube (Liddelow, 2015), and may share some of the response to SARS-CoV-2 infection as the retina.

Comparison of the DE genes of infected retinal organoids after 24 hours incubation to those of infected choroid plexus organoids after a similar incubation, identified 35 genes that are upregulated and 12 genes that are downregulated in both organoid systems (Figure 4D). Of the genes upregulated in both systems, 17 were highly upregulated in the retinal organoids (fold change $\geq 2$ ). GO analysis identified enriched categories related to megakaryocyte differentiation, negative regulation of SMAD signaling and serine-threonine phosphorylation, peptidyl-tyrosine phosphorylation, and cell proliferation (Table 2). Interestingly, GO of genes that are specifically highly upregulated in the infected retinal organoids (and are not upregulated in the choroid plexus organoids) identified several enriched categories related to TGF $\beta$ and BMP signaling response (Table 2). Such a result suggests a difference in TGF $\beta$ response to SARS-CoV-2 infection between the retina and choroid plexus. 
Unlike the choroid plexus organoids, retinal organoids show upregulation of the cytokine interleukin 33 (IL33), the most upregulated (Fold change $=8.11$, FDR adjusted P-value $=$ 4.27E-7) cytokine in these organoids. Accordingly, an immunohistochemical analysis identified several IL33+ cells in infected organoids, but hardly any in the controls (Figure E). Thus, SARS-CoV-2 retinal infection appears to induce IL33 expression. IL33 signaling is thought to play a role in COVID-19 pathology (Zizzo and Cohen, 2020), as well as in retinal inflammation and photoreceptor degradation following injury (Xi et al., 2016).

Another interesting inflammation-related gene found to be upregulated in SARS-CoV-2infected retinal organoids is the inflammasome gene NLRP1 (fold change 2.2, adjusted P-value $=0.0346)$. NLRP1 inflammasomes are thought to be involved in RGC death in acute glaucoma (Yerramothu et al., 2018).

Interestingly, the top five categories enriched in the genes most significantly downregulated in infected retinal organoids (FDR adjusted P-value $\leq 0.05$, fold change $\leq-2$ ) are all related to DNA metabolism, repair, and recombination (Figure 4B and Table 1). This might suggest an effect of SARS-CoV-2 on retinal progenitor cells or DNA damage repair mechanisms. Other coronaviruses have been shown to interact with the cell cycle and DNA damage response in different ways (Surjit et al., 2006; Xu et al., 2011; Zhou et al., 2008).

\section{ACE2 blocking successfully reduces SARS-CoV-2 infection of retinal organoids}

In order to assess the extent to which retinal SARS-CoV-2 infection is mediated by ACE2, retinal organoids were treated with an anti-ACE2 antibody that blocks SARS-CoV-2 infection (Hoffmann et al., 2020; Song et al., 2021). Interestingly, retinal organoids that were treated with the anti-ACE2 antibody contained a significantly lower number of SARS-CoV-2 N+ cells compared with organoids from the same batch that were treated with a normal goat $\operatorname{IgG}$ antibody isotype control (1.35 2.02 vs. $6.78 \pm 7.78$, on average, Figure 5A, B and C). Thus, in 
bioRxiv preprint doi: https://doi.org/10.1101/2021.10.09.463766; this version posted October 12,2021 . The copyright holder for this preprint (which was not certified by peer review) is the author/funder, who has granted bioRxiv a license to display the preprint in perpetuity. It is made available under aCC-BY-NC-ND 4.0 International license.

contrast to recent suggestions that SARS-CoV-2 infection of the retina is not mediated by ACE2 (de Figueiredo et al., 2020), our results suggest that SARS-CoV-2 infection of retinal cells is dependent upon functional ACE2 receptors.

\section{Discussion}

\section{SARS-CoV-2 can actively infect retinal neurons}

Retinal organoids show high similarity to the developing human retina in both morphology and transcriptome (Sridhar et al., 2020), rendering them a potent model for studying the biology of the human retina. Our data establishes retinal organoids as a potent model to study retinal involvement in COVID-19. A recently published paper showed that a recombinant lentiviral vector carrying the SARS-CoV-2 spike protein can infect retinal organoids (Ahmad Mulyadi Lai et al., 2021). Our data goes beyond that, showing that SARS-CoV-2 itself infects retinal organoids, and more importantly, we provide the first evidence that SARS-CoV-2 can actively replicate in retinal tissue.

Interestingly, younger retinal organoids appeared to be more permissive to infection than older ones. TMPRSS2 expression, which is known to be important in SARS-CoV-2 infection, was shown to be decreased in retinal organoids over time (Ahmad Mulyadi Lai et al., 2021). This might suggest that more mature retinal cells are less likely to be infected by SARS-CoV-2 because of changes in TMPRSS2 expression. Yet, the mRNA expression of TMPRSS2 in our retinal organoids was extremely low on day 80 , suggesting that there is minimal involvement of TMPRSS2 in retinal SARS-CoV-2 infection.

In older retinal organoids, mature retinal cells were also infected, albeit at a lower number, indicating that mature retinal cells are still susceptible to SARS-CoV-2 infection. In fact, in the organoids, progenitor cells were less likely to be infected than differentiated neurons, emphasizing the susceptibility of retinal neurons to infection. As retinal organoids differentiate, 
the number of cells contained therein increases, potentially increasing the organoid density. As organoids lack vascularization, an increase in their density and size might decrease the permeability of the inner layers to SARS-CoV-2 and decrease the likelihood of viral infection of inner retinal cells.

Moreover, changes in the cell type composition might affect the infectability of the organoids. Loss of RGCs is known to occur during maturation of human retinal organoids, with nearly complete depletion of RGCs at the late stages (Sridhar et al., 2020; Zhong et al., 2014). The observed decrease in SARS-CoV-2-infected cells during retinal organoid maturation might be related to changes in the number of RGCs over time. Indeed, while our analysis identified SARS-CoV-2-infected cells from different retinal lineages, RGCs were significantly more likely to be infected.

Interestingly, many of the retinal symptoms associated with COVID-19, such as lesions in the GCL (Marinho et al., 2020) and swelling of the optic nerve (Burgos-Blasco et al., 2020), are related to RGCs. Pathology of the GCL could be the result of several issues, such as vascular dysfunction or increase in ocular pressure, and thus might be a secondary effect to other symptoms of the disease. Yet, as SARS-CoV-2 targets organoids RGCs, infection of RGCs may have such direct pathological consequences.

RGCs are the cells that generate the optic nerve and connect the retina to the rest of the CNS. Viruses, such as the herpes simplex virus type 1, can be anterogradely transferred from the retina through the optic nerve into its targets in the brain (Sun et al., 1996). Considering this, the possibility that the retina represents a potential entry route for SARS-CoV-2 into the rest of the CNS should be considered. A recent publication suggested that SARS-CoV-2 can infect many non-retinal ocular cell tissues such as the cornea, the sclera, the choroid, the limbus and the RPE, indicating the possibility of SARS-CoV-2 infection through the eye (Eriksen et al., 
bioRxiv preprint doi: https://doi.org/10.1101/2021.10.09.463766; this version posted October 12,2021 . The copyright holder for this preprint (which was not certified by peer review) is the author/funder, who has granted bioRxiv a license to display the preprint in perpetuity. It is made available under aCC-BY-NC-ND 4.0 International license.

2021). Taken together, these results may suggest a direct route for SARS-CoV-2 infection from exposed ocular surface tissues like the cornea to the CNS through the retina.

\section{SARS-CoV-2 infection of retinal organoids induces inflammatory genes}

The pathology of COVID-19 is highly attributed to uncontrolled hyperinflammation, referred to as a cytokine storm (Burke et al., 2020; Mehta et al., 2020). Our data suggests that the infection of retinal organoids results in the upregulation of several inflammatory genes. Among these are several genes involved in the immune response to viral infection, such as the chemokine CXCL10 (Trifilo et al., 2004) and the interferon-induced gene IFTIM1 (Brass et al., 2009), suggesting that SARS-CoV-2 infection triggers an inflammatory response.

The most significantly upregulated cytokine in infected retinal organoids was IL33. Several studies have identified a strong correlation between COVID 19 disease severity and the levels of IL33 in the blood serum of patients (Burke et al., 2020; Munitz et al., 2021). In the mature retina, IL33 is expressed mainly by Müller glia and RPE cells (Xi et al., 2016). Elevated expression and secretion of IL33 in the rodent retina were shown to be the result of different harmful stimuli such as infection with Toxoplasma gondii, retinal detachment, and lightinduced damage (Augustine et al., 2019; Tong and Lu, 2015; Xi et al., 2016). While suggested to have a protective role in a mouse model of retinal detachment (Augustine et al., 2019), IL33 was shown to pathologically amplify the innate immune response in the rat retina following light-induced damage or RPE disruption, promoting the expression of inflammatory chemokines and cytokines from Müller glia, the accumulation of myeloid cells in the outer nuclear layer, and RGC and photoreceptor cell death (Xi et al., 2016).

Thus, our data suggests that SARS-CoV-2 infection of retinal cells results in an inflammatory response of immune system factors such as IL33 and NLRP1 which are involved in retinal degenerative diseases causing irreversible blindness. Cytokines that were up-regulated in the 
infected organoids, may prove to be worthy candidates for further studies regarding COVID19 retinal pathology.

Comparison of the DE genes in retinal organoids and choroid plexus organoids identified enrichment of TGF $\beta$ response genes among genes which were induced in the retinal but not in the choroid plexus organoids, suggesting that SARS-CoV-2 infection may induce differential TGF $\beta$ response in different systems.

The eye is an immune-privileged organ, as different mechanisms reduce its inflammatory responses in order to prevent vision impairment. TGF $\beta$ signaling has an important role in maintaining the immune-privileged status of the eye (Masli and Vega, 2011; Zhou and Caspi, 2010). For example, both RPE cells and RGCs suppress the activation of $T$ cells via the secretion of TGF $\beta$ molecules (Edo et al., 2020; Sugita et al., 2011). Unlike most of the CNS, the choroid plexus is not an immune-privileged structure (Galea et al., 2007). Thus, differences in TGF $\beta$ response of retinal and choroid plexus organoids to SARS-CoV-2 infection may be related to the immunosuppressive role of TGF $\beta$.

\section{SARS-CoV-2 retinal infection is dependent on ACE2}

The relatively low expression of ACE2 in the retina has led researchers to speculate that SARSCoV-2 retinal infection is dependent upon alternate pathways (de Figueiredo et al., 2020). Yet, ACE2 protein was identified in human retinas and retinal organoids (Ahmad Mulyadi Lai et al., 2021; Senanayake et al., 2007). Our data indicates that the infection of retinal cells can be blocked by using anti-ACE2 antibodies. Thus, the infection of retinal cells most likely is primarily dependent upon functional ACE2 receptors. The possibility of blocking retinal infection by using ACE2 antibodies may also be helpful for the development of drugs in the treatment of SARS-CoV-2 retinal infection. 
To conclude, our data indicates that SARS-CoV-2 can actively infect retinal cells in an ACE2dependent manner. Further studies should consider the possibility that neuro-retinal infection leads to retinal symptoms in patients with COVID-19 and perhaps examine potential treatment options. SARS-CoV-2-dependent photoreceptor and/or RGC degeneration can cause permanent visual impairment or even blindness. While data suggesting vision impairment in patients with COVID-19 is scarce, it should be noted that visual impairment and subsequent blindness from retinal degenerative diseases may become evident only after a long course of progression. Long-Covid- or Post-Covid-Syndrome-related vision impairment or even blindness may occur at a much later time point after an acute SARS-CoV-2 infection. The induction of inflammatory genes that are related to retinal degeneration in the organoids should prompt further investigation of the association between SARS-CoV-2 infection and retinal degenerative diseases.

While our study indicates that SARS-CoCV-2 can infect and replicate in retinal cells in organoids, our experimental system has some limitations. Retinal organoids contain some RPE tissue together with neuro-retinal tissue but are devoid of other important tissues such as the cornea and the retinal vasculature present in the physiological environment (Achberger et al., 2019). This limits the ability to use the retinal organoid model to study the entry and route of SARS-CoV-2 infection in the retina and the interaction between the retina and other tissues during infection. Moreover, retinal organoids lack specialized immune cells such as microglia, which have an important role in retinal inflammation (Rashid et al., 2019), and thus cannot be used to fully characterize the retinal inflammatory response to SARS-CoV-2. Retinal organoids also represent the embryonic retina rather than a mature retina, and thus some age-related differences might affect retinal SARS-CoV-2 infection and pathology. Yet, the fact that SARSCoV-2 also does infect relatively mature neurons and cause the upregulation of inflammatory genes in our organoids, combined with the growing evidence of retinal involvement in patients 
bioRxiv preprint doi: https://doi.org/10.1101/2021.10.09.463766; this version posted October 12,2021 . The copyright holder for this preprint (which was not certified by peer review) is the author/funder, who has granted bioRxiv a license to display the preprint in perpetuity. It is made available under aCC-BY-NC-ND 4.0 International license.

with COVID-19, indicates the relevance of the data produced from our retinal organoids and the need for further investigations into COVID-19-related retinal pathologies.

\section{METHODS}

\section{Organoid production}

H9 human embryonic stem cells (HESCs) and Gibco episomal iPSCs (line A18945) were grown in feeder-free conditions in Matrigel (Corning)-coated plates in StemFlex medium (Thermo Fisher). To produce organoids, we have combined different widely used retinal organoid generation protocols (Capowski et al., 2019; Kuwahara et al., 2015; Zhong et al., 2014). In short, HESCs or IPSCs were grown until they reached $\sim 80 \%$ confluence. At that stage, cell colonies were detached from the plate using $0.5 \mathrm{mM}$ EDTA and placed in a low attachment 6-well plate (MERK) well in $1 \mathrm{~mL}$ of mTeSR1 medium (Stem cell technologies) containing $10 \mu \mathrm{M}$ of Blebbistatin (Sigma-Aldrich) per well. Over the next three days, the medium was replaced gradually to neural induction medium (NIM) comprising DMEM/F12 (Thermo Fisher) 1:1, 1\% N2 (Thermo Fisher), 1 x MEM nonessential amino acids (Thermo Fisher), 1 x Glutamax (Thermo Fisher), and $2 \mu \mathrm{g} / \mathrm{mL}$ of heparin (Sigma-Aldrich). On day 6 of differentiation, NIM was replaced and supplemented with $1.5 \mathrm{nM}$ of BMP4 (R\&D Systems). Half of the media was replaced on days 9,12 , and 15 of differentiation with fresh NIM to dilute the BMP4 concentration. On day 16, NIM was replaced with retinal differentiation medium (RDM) comprising DMEM:F12 3:1, 2\% B27 (Thermo Fisher), 1x MEM nonessential amino acids, 1x Penicillin-Streptomycin (Thermo Fisher), and 1x Glutamax. From this stage onward, the RDM medium was changed twice a week. On day 30 of differentiation, RDM was supplemented with $10 \%$ FBS and $100 \mu \mathrm{M}$ of taurine (Sigma-Aldrich). Between days 40 and day 100 of differentiation, RDM was also supplemented with $1 \mu \mathrm{M}$ of all-trans-retinoic acid (Sigma-Aldrich). 


\section{Virus production and organoid infection}

SARS-CoV-2 was isolated from a patient in South Tyrol (hCoV19/Germany/FI1103201/2020) and identified as type "Ischgl". The virus sequence is available in the GSAID data bank under EPI-ISL_463008)

All SARS-CoV-2-containing experiments were conducted under biosafety level (BSL) 3 conditions. The virus was propagated on VeroE6-TMPRSS2 cells using DMEM (Sigma) supplemented with 2\% (v/v) FBS (Capricon Scientific), 1\% (v/v) Penicillin/Streptomycin (Sigma), 1\% (v/v) sodium pyruvate solution (Sigma), 1\% (v/v) NEAA (Sigma), and 1\% (v/v) HEPES solution (Sigma) using an MOI of 0.01. Two days post-infection, the virus titer was determined.

SARS-CoV-2 was diluted to the desired amounts in RDM supplemented with $100 \mu \mathrm{M}$ of taurine (Sigma-Aldrich) without FBS. The organoids were washed twice with PBS and incubated for $1 \mathrm{~h}$ at $37^{\circ} \mathrm{C}$ with the virus dilutions. Afterward, organoids were washed once with PBS and incubated in RDM supplemented with $100 \mu \mathrm{M}$ of taurine for specific time points.

\section{Plaque assay}

VeroE6 cells were grown to a confluent monolayer in 6-well plates. 10-fold dilution series of viral solutions were prepared in PBS (Sigma) containing 1\% (v/v) Penicillin/Streptomycin, $0.6 \%$ (v/v) BSA (35\%) (Sigma), $0.01 \%(\mathrm{w} / \mathrm{v}) \mathrm{CaCl}_{2}(1 \%)$, and $0.01 \%(\mathrm{w} / \mathrm{v}) \mathrm{MgCl}_{2}(1 \%)$. The VeroE6 cells were incubated with the dilution series for $1 \mathrm{~h}$ at $37^{\circ} \mathrm{C}$. Afterwards the inoculum was replaced by plaque medium (63\% (v/v) 2x MEM [20\% (v/v) 10x MEM (Gibco), 3.2\% (v/v) $\mathrm{NaHCO}_{3}$ (Lonza), 2\% (v/v) HEPES (1M; pH 7.2) (Sigma), 1.2\% (v/v) BSA (35\%), 1\% (v/v) 100x Penicillin/Streptomycin/L-Glutamine solution (10.000 U/ml Pen.; $10.000 \mu \mathrm{g} / \mathrm{ml}$ Strep., 29.2 mg/ml L-Glutamine) (Gibco)], 2\% (v/v) FBS, and 35\% (v/v) Agar (2\%) (Oxoid)). After $48 \mathrm{~h}$ to $96 \mathrm{~h}$, plaques were counted. 


\section{Immunohistochemistry}

Organoids were fixed in 4\% PFA for 30 minutes (organoids used for ACE2 immunohistochemistry were fixed for 2 hours), washed three times in PBS, and incubated overnight at $4{ }^{\circ} \mathrm{C}$ in $30 \%$ sucrose in PBS. The organoids were then cryopreserved in O.C.T (Tissue-Tek) and sectioned to a thickness of $20 \mu \mathrm{m}$. The sections were blocked and permeabilized with 10\% normal donkey serum (Abcam) and $0.3 \%$ Triton X in PBS for 1 hour at room temperature (RT), and then incubated with the primary antibodies diluted in blocking medium overnight at $4{ }^{\circ} \mathrm{C}$. The primary antibodies used for the study can be found in table S1. Sections were further washed and incubated with a species-specific secondary fluorescent antibody, together with DAPI, for 1 hour in the dark at RT and then mounted. Imaging was done using an LSM 780 scanning confocal microscope (Zeiss). All images presented here are maximal projection images. Cell counting was performed manually on random sections from different organoids, with a similarly sized area.

\section{RNA extraction and cDNA library preparation and RNA sequencing}

RNA from mock-treated and infected organoids was extracted with TRIzol@ reagent according to the manufacturer's protocol with minor modifications. Briefly, washed retina organoids were resuspended in $700 \mu \mathrm{L}$ of TRIzol reagent. The tissue was disrupted mechanically by vortexing for $30 \mathrm{sec}$ and pipetting 20 times. $140 \mu \mathrm{L}$ of chloroform was added and samples were mixed vigorously for $15 \mathrm{sec}$. Following centrifugation at $4^{\circ} \mathrm{C}$, the aqueous phase was carefully separated and RNA was further precipitated by $350 \mu \mathrm{L}$ of 2-propanol. RNA pellets were washed twice with 75\% ethanol and resuspended in DEPC-treated water for further library preparation. 
bioRxiv preprint doi: https://doi.org/10.1101/2021.10.09.463766; this version posted October 12,2021 . The copyright holder for this preprint (which was not certified by peer review) is the author/funder, who has granted bioRxiv a license to display the preprint in perpetuity. It is made available under aCC-BY-NC-ND 4.0 International license.

$600 \mathrm{ng}$ of total RNA was used for RNA isolation, fragmentation, and cDNA synthesis using the NEBNExt ${ }^{\circledR}$ Poly(A) mRNA magnetic isolation module (E7490). cDNA libraries were amplified and index labeled using the NEBNext巴 ${ }^{\circledR}$ Ultra TM II RNA Library Prep kit for Illumina ${ }^{\circledR}(E 7770$, E7775). DNA library quality and concentration were analyzed on an Agilent Bioanalyzer DNA Chip. cDNA samples were loaded on a NextSeq 2000 system (Illumina) at a concentration of $800 \mathrm{pMol}$, and the sequencing was performed with single-end 100 -bp reads.

\section{Bioinformatic analysis}

The sequencing data was first demultiplexed using the Illumina software bcl2fastq v2.20.0. The quality of the resulting FASTQ files was then evaluated with the program FastQC v0.11.8 (https://www.bioinformatics.babraham.ac.uk/projects/fastqc/).

To perform the alignment, a customized combination of the human genome and the SARSCoV-2 viral genome was created. The reference sequence and gene annotation for SARSCoV-2 were obtained from the NCBI repository, from the entry with accession number NC_045512.2 "Severe acute respiratory syndrome coronavirus 2 isolate Wuhan-Hu-1, complete genome". The human genome sequence and gene annotation were also obtained from NCBI, using the assembly version GRCh38.p13. Both viral and human genomes were concatenated using a customized bash script to create the alignment reference sequence and annotation files. Finally, the alignment was performed using STAR v2.7.7a (Dobin et al., 2013) with default parameters and the extra instruction "--quantMode GeneCounts" to create additional gene count tables.

The following secondary analysis was performed in the statistical environment $\mathrm{R}$ v4.0.3 (https://www.r-project.org/). After importing the gene count tables, only genes that had a minimum of 5 reads in at least 3 samples were kept as a quality filter. Then, a dispersion trend 
among the samples was assessed with a principal component analysis (PCA) applied over the normalized read counts, transformed through the regularized log transformation (Figure S1B). Differential gene expression was assessed based on a Negative Binomial distribution through the package DEseq2 v1.30.1 (Love et al., 2014). Genes were considered as differentially expressed (DE) if they presented an absolute value of fold change of $>1$ and a BenjaminiHochberg FDR of $\leq 5 \%$. A very small number of SARS-CoV-2 transcripts was identified in one of the three 24-hour control samples, yet considering the vast difference in scale between the levels of SARS-CoV-2 transcripts in this sample and the levels found in the infected samples (Figure 4A, fold change $>200$ ), these transcripts most likely do not represent a SARSCoV-2 infection in this sample. In addition, this sample clustered together with the other control samples in a PCA analysis (Figure S1B). Thus, we decided to include this sample in the analysis.

Heatmap representation of the expression of selected genes was created with the package pheatmap v1.0.12 using the values obtained after applying the regularized log transformation over the raw counts.

GO and KEGG pathway analyses were performed by separately collecting all upregulated genes with a fold change of $\geq 2$ and all downregulated genes with a fold change of $\leq-2$ and uploading the gene lists to the Enrichr software (Chen et al., 2013; Kuleshov et al., 2016).

\section{Real-time PCR}

cDNA synthesis was performed using the High-Capacity cDNA Reverse Transcription Kit (Applied Biosystems). Real-time PCR was performed using iTaq SYBRGreen Supermix with ROX (Bio-Rad) and a QuantStudio3 machine (applied biosystems). Gene expression was normalized according to the housekeeping gene GAPDH and calculated using the delta CT method. Primers used in this research can be found in table S2. 


\section{ACE2 blocking}

Retinal organoids on day 90 of differentiation were incubated at RT for 1 hour in PBS with either a goat anti-ACE2 antibody (AF933, R\&D Systems) or a normal goat IgG control (AB108-C, R\&D Systems), at a concentration of $100 \mu \mathrm{g} / \mathrm{mL}$ before being infected with SARSCoV-2.

\section{Statistical analysis}

Statistical analysis was done using GraphPad Prism 9. Analysis of experiments with multiple groups was done by a one-way ANOVA with Tukey's multiple comparison test. Statistical analysis of experiments with only two groups was done using an unpaired, two-tailed Student's t-test. No statistical tests were used to predetermine the sample size.

\section{Data availability}

Raw and processed RNA-seq data was uploaded to GEO.

Acknowledgements: This research was supported by the Max Planck Society's White PaperProject: Brain Organoids: Alternatives to Animal Testing in Neuroscience. Further financial support was received from the German Research Foundation (DFG), grant SFB1009 B13, and the German Ministry of Education and Research (BMBF), project OrganoStrat (01KX2021), SFB944 (Z-Project) and the IZKF, grant Bru2/015/19. We thank Ingrid Gelker and Manuela Haustein for their technical help. We also thank the team of the Core Facility Genomik in the medical faculty in Münster for RNA-sequencing and Areti Malapetsas for editing the manuscript.

\section{Author contributions}


YML, AS, SL, TR and HRS conceived the study.

YML and TR wrote the manuscript and prepared the figures.

YML, AS, AMZ, LB and OEP performed experiments.

AL analyzed data

All authors contributed to the editing of the manuscript

\section{References}

Achberger, K., Haderspeck, J.C., Kleger, A., and Liebau, S. (2019). Stem cell-based retina models. Adv Drug Deliver Rev 140, 33-50.

Ahmad Mulyadi Lai, H.I., Chou, S.J., Chien, Y., Tsai, P.H., Chien, C.S., Hsu, C.C., Jheng, Y.C., Wang, M.L., Chiou, S.H., Chou, Y.B., et al. (2021). Expression of Endogenous AngiotensinConverting Enzyme 2 in Human Induced Pluripotent Stem Cell-Derived Retinal Organoids. Int J Mol Sci 22.

Asadi-Pooya, A.A., and Simani, L. (2020). Central nervous system manifestations of COVID19: A systematic review. J Neurol Sci 413, 116832.

Augustine, J., Pavlou, S., Ali, I., Harkin, K., Ozaki, E., Campbell, M., Stitt, A.W., Xu, H., and Chen, M. (2019). IL-33 deficiency causes persistent inflammation and severe neurodegeneration in retinal detachment. J Neuroinflammation 16, 251.

Brass, A.L., Huang, I.C., Benita, Y., John, S.P., Krishnan, M.N., Feeley, E.M., Ryan, B.J., Weyer, J.L., van der Weyden, L., Fikrig, E., et al. (2009). The IFITM proteins mediate cellular resistance to influenza A H1N1 virus, West Nile virus, and dengue virus. Cell 139, 1243-1254. Burgos-Blasco, B., Guemes-Villahoz, N., Donate-Lopez, J., Vidal-Villegas, B., and GarciaFeijoo, J. (2020). Optic nerve analysis in COVID-19 patients. J Med Virol.

Burke, H., Freeman, A., Cellura, D.C., Stuart, B.L., Brendish, N.J., Poole, S., Borca, F., Phan, H.T.T., Sheard, N., Williams, S., et al. (2020). Inflammatory phenotyping predicts clinical outcome in COVID-19. Respir Res 21, 245.

Butler, D., Mozsary, C., Meydan, C., Foox, J., Rosiene, J., Shaiber, A., Danko, D., Afshinnekoo, E., MacKay, M., Sedlazeck, F.J., et al. (2021). Shotgun transcriptome, spatial omics, and isothermal profiling of SARS-CoV-2 infection reveals unique host responses, viral diversification, and drug interactions. Nat Commun 12, 1660.

Capowski, E.E., Samimi, K., Mayerl, S.J., Phillips, M.J., Pinilla, I., Howden, S.E., Saha, J., Jansen, A.D., Edwards, K.L., Jager, L.D., et al. (2019). Reproducibility and staging of 3D human retinal organoids across multiple pluripotent stem cell lines. Development 146. Casagrande, M., Fitzek, A., Puschel, K., Aleshcheva, G., Schultheiss, H.P., Berneking, L., Spitzer, M.S., and Schultheiss, M. (2020). Detection of SARS-CoV-2 in Human Retinal Biopsies of Deceased COVID-19 Patients. Ocul Immunol Inflamm, 1-5.

Casagrande, M., Fitzek, A., Spitzer, M., Puschel, K., Glatzel, M., Krasemann, S., Aepfelbacher, M., Norz, D., Lutgehetmann, M., Pfefferle, S., et al. (2021). Detection of SARS-CoV-2 genomic and subgenomic RNA in retina and optic nerve of patients with COVID-19. Br J Ophthalmol.

Chen, E.Y., Tan, C.M., Kou, Y., Duan, Q., Wang, Z., Meirelles, G.V., Clark, N.R., and Ma'ayan, A. (2013). Enrichr: interactive and collaborative HTML5 gene list enrichment analysis tool. BMC Bioinformatics 14, 128. 
Conrady, C.D., Faia, L.J., Gregg, K.S., and Rao, R.C. (2021). Coronavirus-19-Associated Retinopathy. Ocul Immunol Inflamm, 1-2.

de Figueiredo, C.S., Raony, I., and Giestal-de-Araujo, E. (2020). SARS-CoV-2 Targeting the Retina: Host-virus Interaction and Possible Mechanisms of Viral Tropism. Ocul Immunol Inflamm, 1-4.

Dobin, A., Davis, C.A., Schlesinger, F., Drenkow, J., Zaleski, C., Jha, S., Batut, P., Chaisson, M., and Gingeras, T.R. (2013). STAR: ultrafast universal RNA-seq aligner. Bioinformatics 29, 1521.

Edo, A., Sugita, S., Futatsugi, Y., Sho, J., Onishi, A., Kiuchi, Y., and Takahashi, M. (2020). Capacity of Retinal Ganglion Cells Derived from Human Induced Pluripotent Stem Cells to Suppress T-Cells. Int J Mol Sci 21.

Eriksen, A.Z., Moller, R., Makovoz, B., Uhl, S.A., tenOever, B.R., and Blenkinsop, T.A. (2021). SARS-CoV-2 infects human adult donor eyes and hESC-derived ocular epithelium. Cell Stem Cell.

Galea, I., Bechmann, I., and Perry, V.H. (2007). What is immune privilege (not)? Trends Immunol 28, 12-18.

Hoffmann, M., Kleine-Weber, H., Schroeder, S., Kruger, N., Herrler, T., Erichsen, S., Schiergens, T.S., Herrler, G., Wu, N.H., Nitsche, A., et al. (2020). SARS-CoV-2 Cell Entry Depends on ACE2 and TMPRSS2 and Is Blocked by a Clinically Proven Protease Inhibitor. Cell $181,271-280$ e278.

Huang, C., Wang, Y., Li, X., Ren, L., Zhao, J., Hu, Y., Zhang, L., Fan, G., Xu, J., Gu, X., et al. (2020). Clinical features of patients infected with 2019 novel coronavirus in Wuhan, China. Lancet 395, 497-506.

Jacob, F., Pather, S.R., Huang, W.K., Zhang, F., Wong, S.Z.H., Zhou, H., Cubitt, B., Fan, W., Chen, C.Z., Xu, M., et al. (2020). Human Pluripotent Stem Cell-Derived Neural Cells and Brain Organoids Reveal SARS-CoV-2 Neurotropism Predominates in Choroid Plexus Epithelium. Cell Stem Cell 27, 937-950 e939.

Kuleshov, M.V., Jones, M.R., Rouillard, A.D., Fernandez, N.F., Duan, Q., Wang, Z., Koplev, S., Jenkins, S.L., Jagodnik, K.M., Lachmann, A., et al. (2016). Enrichr: a comprehensive gene set enrichment analysis web server 2016 update. Nucleic Acids Res 44, W90-97.

Kuwahara, A., Ozone, C., Nakano, T., Saito, K., Eiraku, M., and Sasai, Y. (2015). Generation of a ciliary margin-like stem cell niche from self-organizing human retinal tissue. Nat Commun 6, 6286.

Lamers, M.M., Beumer, J., van der Vaart, J., Knoops, K., Puschhof, J., Breugem, T.I., Ravelli, R.B.G., Paul van Schayck, J., Mykytyn, A.Z., Duimel, H.Q., et al. (2020). SARS-CoV-2 productively infects human gut enterocytes. Science.

Liddelow, S.A. (2015). Development of the choroid plexus and blood-CSF barrier. Front Neurosci 9, 32.

Love, M.I., Huber, W., and Anders, S. (2014). Moderated estimation of fold change and dispersion for RNA-seq data with DESeq2. Genome Biol 15, 550.

Mabillard, H., and Sayer, J.A. (2020). Electrolyte Disturbances in SARS-CoV-2 Infection. F1000Res 9, 587.

Mao, L., Jin, H., Wang, M., Hu, Y., Chen, S., He, Q., Chang, J., Hong, C., Zhou, Y., Wang, D., et al. (2020). Neurologic Manifestations of Hospitalized Patients With Coronavirus Disease 2019 in Wuhan, China. JAMA Neurol 77, 683-690.

Marinho, P.M., Marcos, A.A.A., Romano, A.C., Nascimento, H., and Belfort, R., Jr. (2020). Retinal findings in patients with COVID-19. Lancet. 
Masli, S., and Vega, J.L. (2011). Ocular immune privilege sites. Methods Mol Biol 677, 449458.

Mehta, P., McAuley, D.F., Brown, M., Sanchez, E., Tattersall, R.S., Manson, J.J., and HIh Across Speciality Collaboration, U.K. (2020). COVID-19: consider cytokine storm syndromes and immunosuppression. Lancet 395, 1033-1034.

Monteil, V., Kwon, H., Prado, P., Hagelkruys, A., Wimmer, R.A., Stahl, M., Leopoldi, A., Garreta, E., Hurtado Del Pozo, C., Prosper, F., et al. (2020). Inhibition of SARS-CoV-2 Infections in Engineered Human Tissues Using Clinical-Grade Soluble Human ACE2. Cell 181, 905-913 e907.

Munitz, A., Edry-Botzer, L., Itan, M., Tur-Kaspa, R., Dicker, D., Marcoviciu, D., Goren, M.G., Mor, M., Lev, S., Gottesman, T., et al. (2021). Rapid seroconversion and persistent functional IgG antibodies in severe COVID-19 patients correlates with an IL-12p70 and IL-33 signature. Sci Rep 11, 3461.

Nakano, T., Ando, S., Takata, N., Kawada, M., Muguruma, K., Sekiguchi, K., Saito, K., Yonemura, S., Eiraku, M., and Sasai, Y. (2012). Self-formation of optic cups and storable stratified neural retina from human ESCs. Cell Stem Cell 10, 771-785.

Pellegrini, L., Albecka, A., Mallery, D.L., Kellner, M.J., Paul, D., Carter, A.P., James, L.C., and Lancaster, M.A. (2020). SARS-CoV-2 Infects the Brain Choroid Plexus and Disrupts the BloodCSF Barrier in Human Brain Organoids. Cell Stem Cell.

Pereira, L.A., Soares, L.C.M., Nascimento, P.A., Cirillo, L.R.N., Sakuma, H.T., Veiga, G.L.D., Fonseca, F.L.A., Lima, V.L., and Abucham-Neto, J.Z. (2020). Retinal findings in hospitalised patients with severe COVID-19. Br J Ophthalmol.

Pirraglia, M.P., Ceccarelli, G., Cerini, A., Visioli, G., d'Ettorre, G., Mastroianni, C.M., Pugliese, F., Lambiase, A., and Gharbiya, M. (2020). Retinal involvement and ocular findings in COVID19 pneumonia patients. Sci Rep 10, 17419.

Ramani, A., Muller, L., Niklas Ostermann, P., Gabriel, E., Abida-Islam, P., Muller-Schiffmann, A., Mariappan, A., Goureau, O., Gruell, H., Walker, A., et al. (2020). SARS-CoV-2 targets neurons of 3D human brain organoids. EMBO J, e2020106230.

Rashid, K., Akhtar-Schaefer, I., and Langmann, T. (2019). Microglia in Retinal Degeneration. Front Immunol 10, 1975.

Rodriguez-Rodriguez, M.S., Romero-Castro, R.M., Alvarado-de la Barrera, C., GonzalezCannata, M.G., Garcia-Morales, A.K., and Avila-Rios, S. (2021). Optic neuritis following SARSCoV-2 infection. J Neurovirol.

Senanayake, P., Drazba, J., Shadrach, K., Milsted, A., Rungger-Brandle, E., Nishiyama, K., Miura, S., Karnik, S., Sears, J.E., and Hollyfield, J.G. (2007). Angiotensin II and its receptor subtypes in the human retina. Invest Ophthalmol Vis Sci 48, 3301-3311.

Song, E., Zhang, C., Israelow, B., Lu-Culligan, A., Prado, A.V., Skriabine, S., Lu, P., Weizman, O.E., Liu, F., Dai, Y., et al. (2021). Neuroinvasion of SARS-CoV-2 in human and mouse brain. J Exp Med 218.

Sridhar, A., Hoshino, A., Finkbeiner, C.R., Chitsazan, A., Dai, L., Haugan, A.K., Eschenbacher, K.M., Jackson, D.L., Trapnell, C., Bermingham-McDonogh, O., et al. (2020). Single-Cell Transcriptomic Comparison of Human Fetal Retina, hPSC-Derived Retinal Organoids, and Long-Term Retinal Cultures. Cell Rep 30, 1644-1659 e1644.

Sugita, S., Horie, S., Yamada, Y., Kawazoe, Y., Takase, H., and Mochizuki, M. (2011). Suppression of interleukin-17-producing T-helper 17 cells by retinal pigment epithelial cells. Jpn J Ophthalmol 55, 565-575. 
Sun, N., Cassell, M.D., and Perlman, S. (1996). Anterograde, transneuronal transport of herpes simplex virus type 1 strain $\mathrm{H} 129$ in the murine visual system. J Virol 70, 5405-5413. Surjit, M., Liu, B., Chow, V.T., and Lal, S.K. (2006). The nucleocapsid protein of severe acute respiratory syndrome-coronavirus inhibits the activity of cyclin-cyclin-dependent kinase complex and blocks $S$ phase progression in mammalian cells. J Biol Chem 281, 10669-10681. Tikellis, C., Johnston, C.I., Forbes, J.M., Burns, W.C., Thomas, M.C., Lew, R.A., Yarski, M., Smith, A.I., and Cooper, M.E. (2004). Identification of angiotensin converting enzyme 2 in the rodent retina. Curr Eye Res 29, 419-427.

Tong, X., and Lu, F. (2015). IL-33/ST2 involves the immunopathology of ocular toxoplasmosis in murine model. Parasitol Res 114, 1897-1905.

Trifilo, M.J., Montalto-Morrison, C., Stiles, L.N., Hurst, K.R., Hardison, J.L., Manning, J.E., Masters, P.S., and Lane, T.E. (2004). CXC chemokine ligand 10 controls viral infection in the central nervous system: evidence for a role in innate immune response through recruitment and activation of natural killer cells. J Virol 78, 585-594.

Virgo, J., and Mohamed, M. (2020). Paracentral acute middle maculopathy and acute macular neuroretinopathy following SARS-CoV-2 infection. Eye (Lond).

Wu, P., Duan, F., Luo, C., Liu, Q., Qu, X., Liang, L., and Wu, K. (2020). Characteristics of Ocular Findings of Patients With Coronavirus Disease 2019 (COVID-19) in Hubei Province, China.

JAMA Ophthalmol.

Xi, H., Katschke, K.J., Jr., Li, Y., Truong, T., Lee, W.P., Diehl, L., Rangell, L., Tao, J., Arceo, R., Eastham-Anderson, J., et al. (2016). IL-33 amplifies an innate immune response in the degenerating retina. J Exp Med 213, 189-207.

Xu, L.H., Huang, M., Fang, S.G., and Liu, D.X. (2011). Coronavirus infection induces DNA replication stress partly through interaction of its nonstructural protein 13 with the p125 subunit of DNA polymerase delta. J Biol Chem 286, 39546-39559.

Yerramothu, P., Vijay, A.K., and Willcox, M.D.P. (2018). Inflammasomes, the eye and antiinflammasome therapy. Eye (Lond) 32, 491-505.

Zhang, B.Z., Chu, H., Han, S., Shuai, H., Deng, J., Hu, Y.F., Gong, H.R., Lee, A.C., Zou, Z., Yau, T., et al. (2020). SARS-CoV-2 infects human neural progenitor cells and brain organoids. Cell Res 30, 928-931.

Zhong, X., Gutierrez, C., Xue, T., Hampton, C., Vergara, M.N., Cao, L.H., Peters, A., Park, T.S., Zambidis, E.T., Meyer, J.S., et al. (2014). Generation of three-dimensional retinal tissue with functional photoreceptors from human iPSCs. Nat Commun 5, 4047.

Zhou, B., Liu, J., Wang, Q., Liu, X., Li, X., Li, P., Ma, Q., and Cao, C. (2008). The nucleocapsid protein of severe acute respiratory syndrome coronavirus inhibits cell cytokinesis and proliferation by interacting with translation elongation factor 1alpha. J Virol 82, 6962-6971. Zhou, R., and Caspi, R.R. (2010). Ocular immune privilege. F1000 Biol Rep 2.

Zizzo, G., and Cohen, P.L. (2020). Imperfect storm: is interleukin-33 the Achilles heel of COVID-19? Lancet Rheumatol 2, e779-e790.

\section{Figure 1: Human iPSC-derived retinal organoids can be infected by SARS-CoV-2}

Retinal organoids on day 50 of differentiation are shown to contain VSX2+ (green) retinal progenitors and PAX6+ (white)/VSX2- amacrine and retinal ganglion cells (RGCs) (A). On day 143 of differentiation, the organoids are shown to be organized in a layered structure and to contain AP2a+ (white) amacrine and horizontal cells, CRALBP+ (red) Müller glia cells, 
and OTX2+ (green) cells (B). The sketch in (B) depicts the cell types and structure of the vertebrate retina. ONL: outer nuclear layer; OPL: outer plexiform layer; INL: inner nuclear layer; IPL: inner plexiform layer; GCL: ganglion cell layer. On day 143 of differentiation, the photoreceptors in the organoids are stained against the photosensitive proteins L/M-OPN (white) and RHODOPSIN (RHO, red) (C). Real-time PCR identified SARS-CoV-2 genomic RNA within retinal organoids treated with SARS-CoV-2 but not in controls on day 125 (D). A viral plaque assay was used to assess viral titrations in SARS-CoV-2 treated organoids on day $125(\mathbf{E})$. Each repeat $(\mathrm{N}=2)$ in $(\mathbf{D})$ and $(\mathbf{E})$, is a separate group of five organoids infected or not infected in a separate well. Immunofluorescence analysis was used to detect SARSCoV-2 nucleocapsid (N)-positive cells in infected organoids at day 130 (F) or 160 (G) of differentiation.

\section{Figure 2: SARS-CoV-2 nucleocapsid-positive cells are more abundant in retinal organoids infected at an earlier stage of differentiation}

SARS-CoV-2 nucleocapsid (N) immunostaining was used to quantify the number of $\mathrm{N}+$ (green) cells in retinal organoids that were infected at three different time points: day $74(\mathbf{A})$, day 90 (B), and day 130 (C). An age-matched noninfected control for each stage: day 74 (D), Day $90(\mathbf{E})$, and day $130(\mathbf{F})$ is also presented. All organoids were incubated for 96 hours after infection and before fixation. The number of $\mathrm{N}+$ cells counted in the organoids of each stage was compared $(\mathbf{G}) . \mathrm{N}=7$ organoids, taken from two different infected or control wells, ANOVA P-value $=0.0002, \mathrm{~F}=14.15 ; * *: \mathrm{P}$-value $=0.0038 ; * * *: \mathrm{P}$-value $=0.0002$

\section{Figure 3: SARS-CoV-2 infects retinal ganglion cells at a higher rate than other retinal cell types}

Retinal organoids infected with SARS-CoV-2 on day 74 and incubated for $96 \mathrm{~h}$ before fixation were immunostained with antibodies against SARS-CoV-2 nucleocapsid ( $\mathrm{N}$, green) and the retinal ganglion cell marker SNCG (white) (A), the photoreceptor cell marker OTX2 (white) (B), the amacrine and horizontal cell marker AP2 $\alpha$ (red) (B), and the retinal progenitor marker VSX2 (red) (C). The number of cells that were co-stained with $\mathrm{N}$ and each of the markers was quantified, and the percentage of each marker-positive cell type out of the total number of $\mathrm{N}+$ cells was compared (D). $\mathrm{N}=6$ organoids taken from two different infected wells, ANOVA P-value $<0.0001, \mathrm{~F}=21.69$; ****: P-value $<0.0001$; ***: P-value $=$ 0.0008; *: P-value $=0.032$. Sections from day 74-control organoids were also 
immunostained with antibodies against ACE2 (green), together with antibodies against OTX2 (white) and HUC/D (red) (E) and (G). ACE2 staining was compared to sections from the same organoids that were stained with an appropriate rabbit polyclonal antibody isotype control.

\section{Figure 4: A transcriptomic analysis of SARS-CoV-2-infected retinal organoids} RNA was extracted from SARS-CoV-2 infected and control organoids on day 80 of differentiation and incubated for 24 or 96 hours following infection and from their respective controls. $\mathrm{N}=3$ repeats for every treatment. Each repeat included five organoids, that were treated separately from the rest of the samples. SARS-CoV-2 transcripts were identified in large numbers in the infected samples (A). Genes that were significantly differentially expressed (DE) with a fold change of at least 2 (or -2) among all of the samples together were used for gene ontology (GO) analysis using the Erichr software. A heatmap of genes related to the top enriched categories identified in the GO analysis is presented (B). The number of normalized reads of the ACE2 gene in noninfected and infected samples at both incubation times was also extracted from the analysis $(\mathbf{C})$. The DE genes identified in the retinal organoids after 24 hours were compared to the DE genes identified in SARS-CoV-2-infected choroid plexus after 24 hours. The comparison is presented as a Venn diagram (D). Control and retinal organoids infected on day 74 of differentiation and incubated for 24 hours before fixation were immunostained against IL33 (green) and OTX2 (red) (E).

\section{Figure 5: SARS-CoV-2 infection of retinal organoids is at least partially dependent upon ACE2}

SARS-CoV-2 nucleocapsid (N) immunostaining (green) was used to detect SARS-CoV-2infected cells in retinal organoids treated with either a goat IgG anti-ACE2 antibody (A), or a goat IgG isotype control (B) before being infected with SARS-CoV-2 and incubated for 96 hours. The number of $\mathrm{N}+$ cells was quantified and compared between organoids that went through the different treatments $(\mathbf{C}) . \mathrm{N}=14$ organoids for each treatment, taken from three different infected wells; *: P-value (two-tailed) $=0.018$.

\section{Figure S1: Supplementary information to figures 1 and 4}

A retinal organoid derived from $\mathrm{H} 9$ embryonic stem cells stained with an anti-SARS-CoV-2 nucleocapsid (N) antibody (green). Scale bar $=50 \mu \mathrm{M}$. (A). PCA analysis of the different 
infected on noninfected samples was performed using the rlog algorithm (B). MA plot representing the mean expression levels and the fold change of the different genes between the infected samples and the noninfected samples. Significantly differentially expressed genes (adjusted P-value $\leq 0.05$ ) are colored red (C). Venn diagram comparing the differentially expressed genes found in retinal organoids 96 hours post-infection and the differentially expressed genes found in choroid plexus organoids after 72 hours. Only 7 genes are mutually upregulated and 4 genes are mutually downregulated (D). 

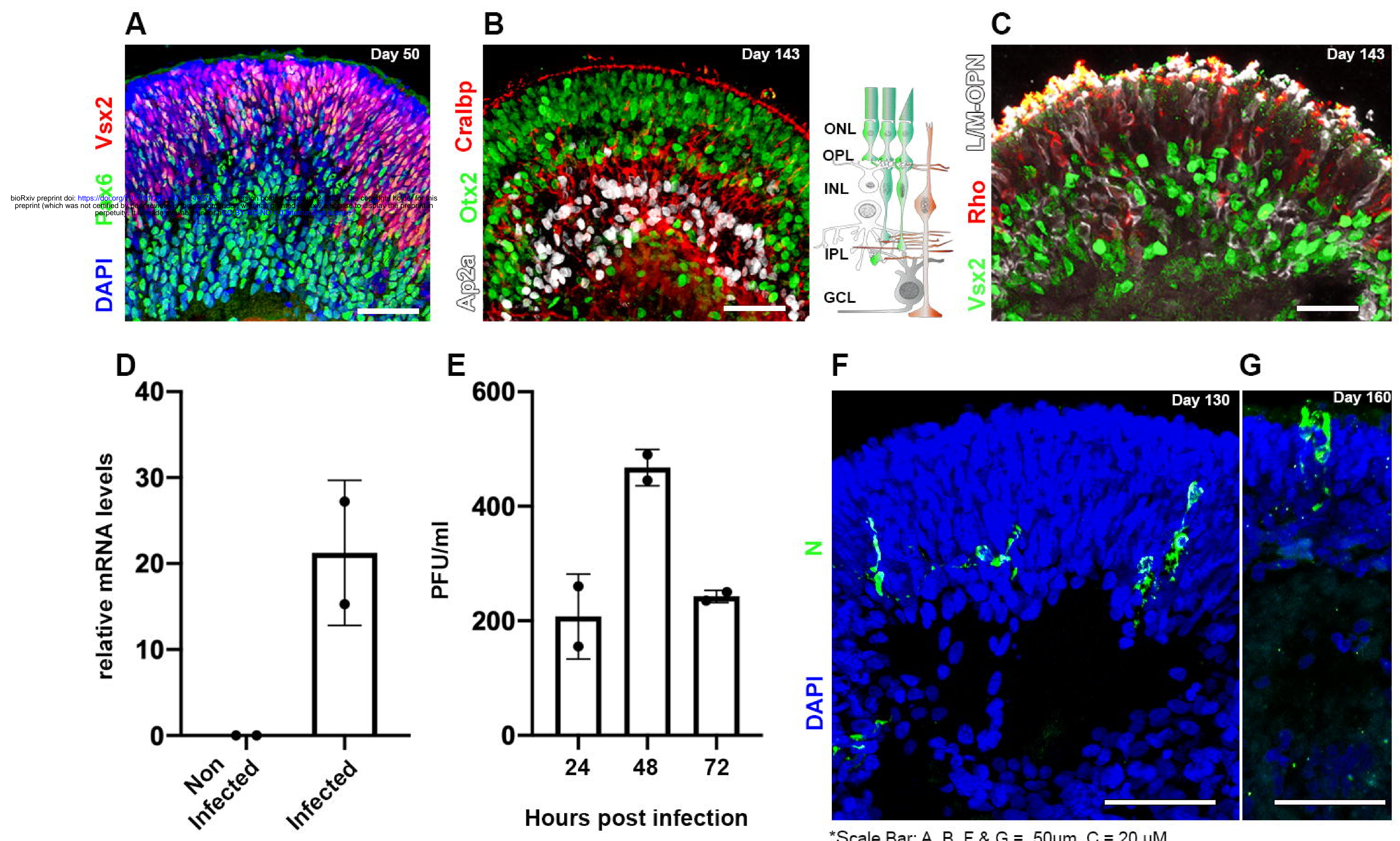

*Scale Bar: A, B, F \& G $=50 \mu \mathrm{m}, \mathrm{C}=20 \mu \mathrm{M}$ 
A

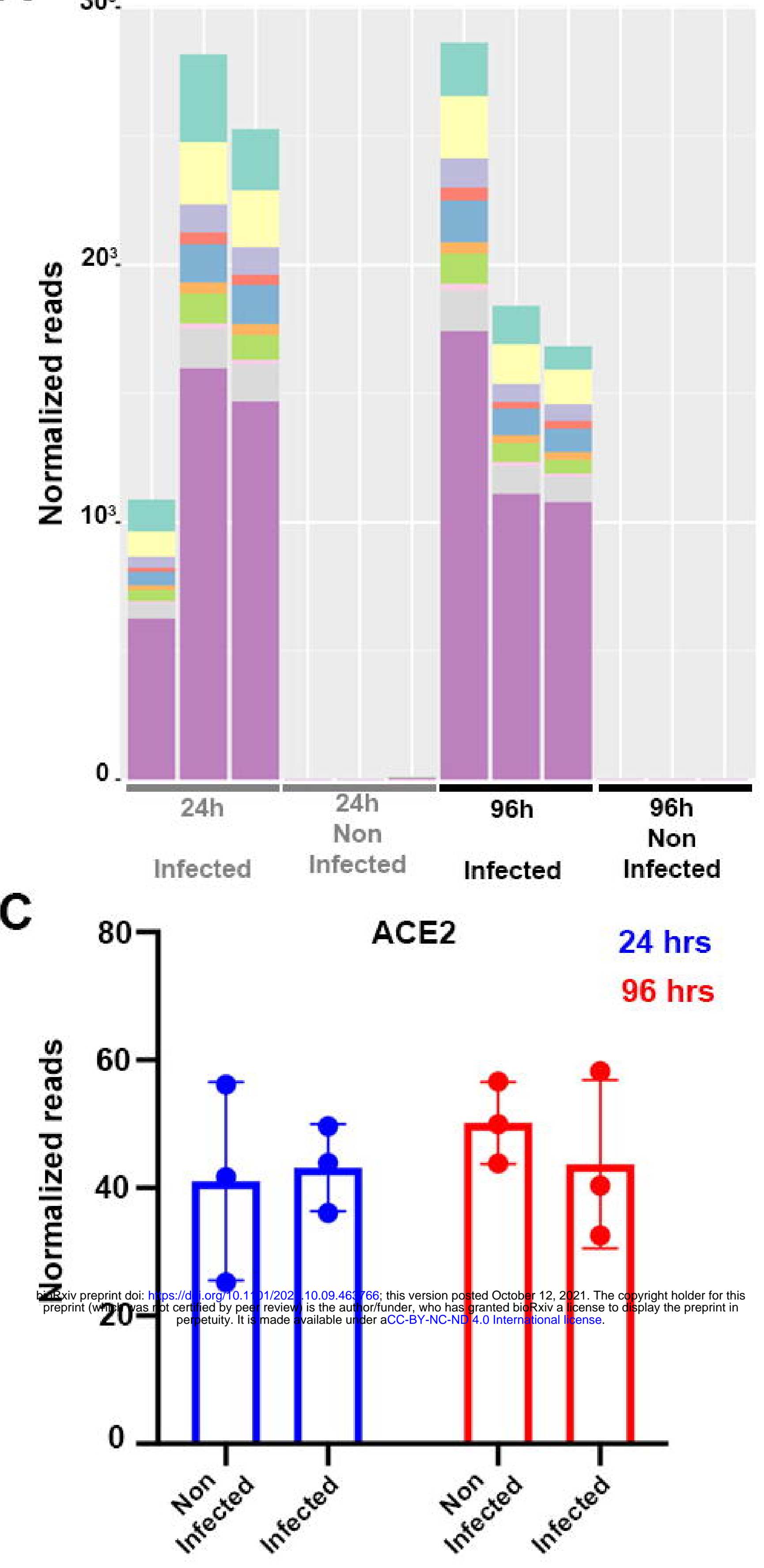

D

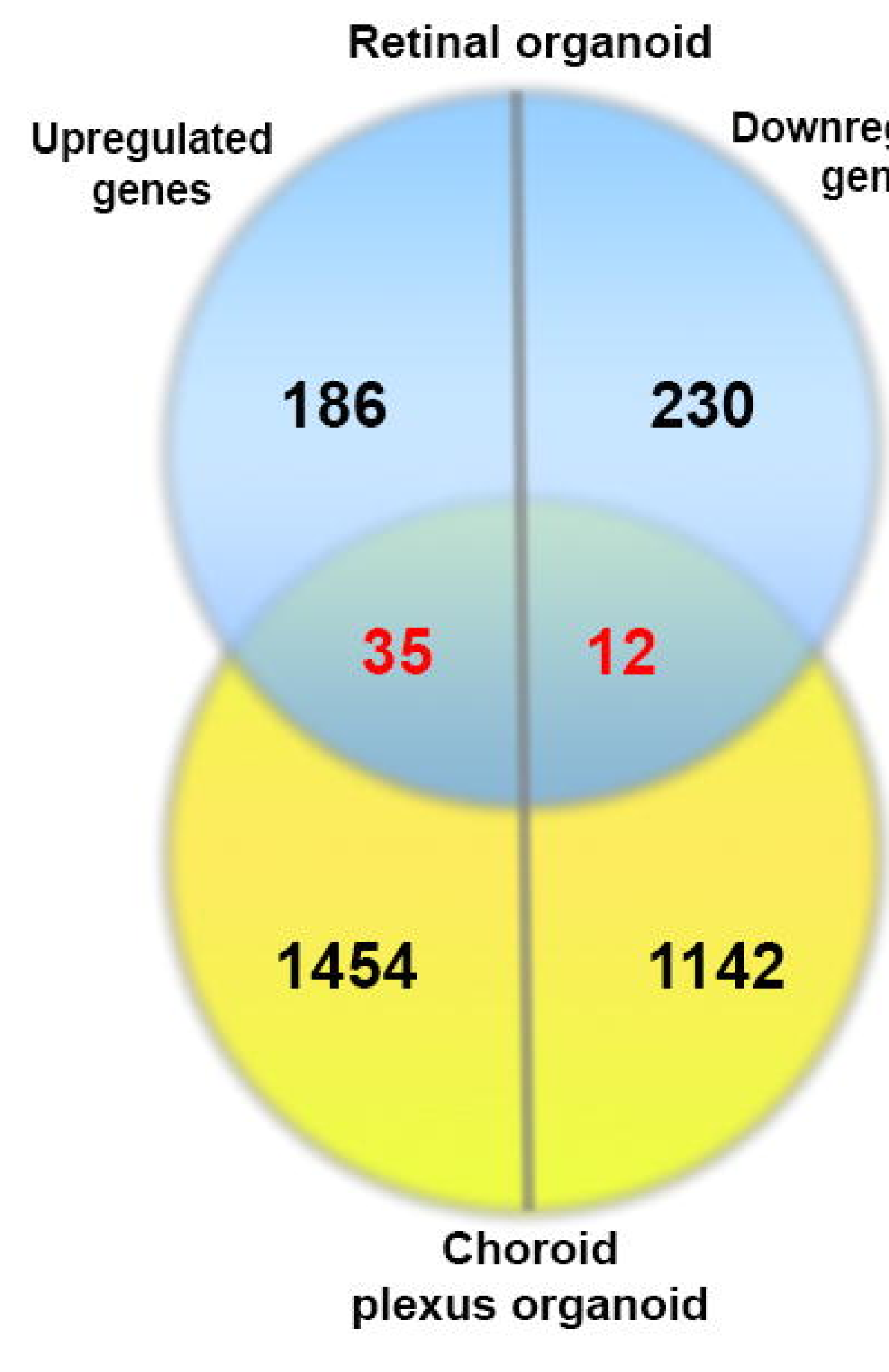

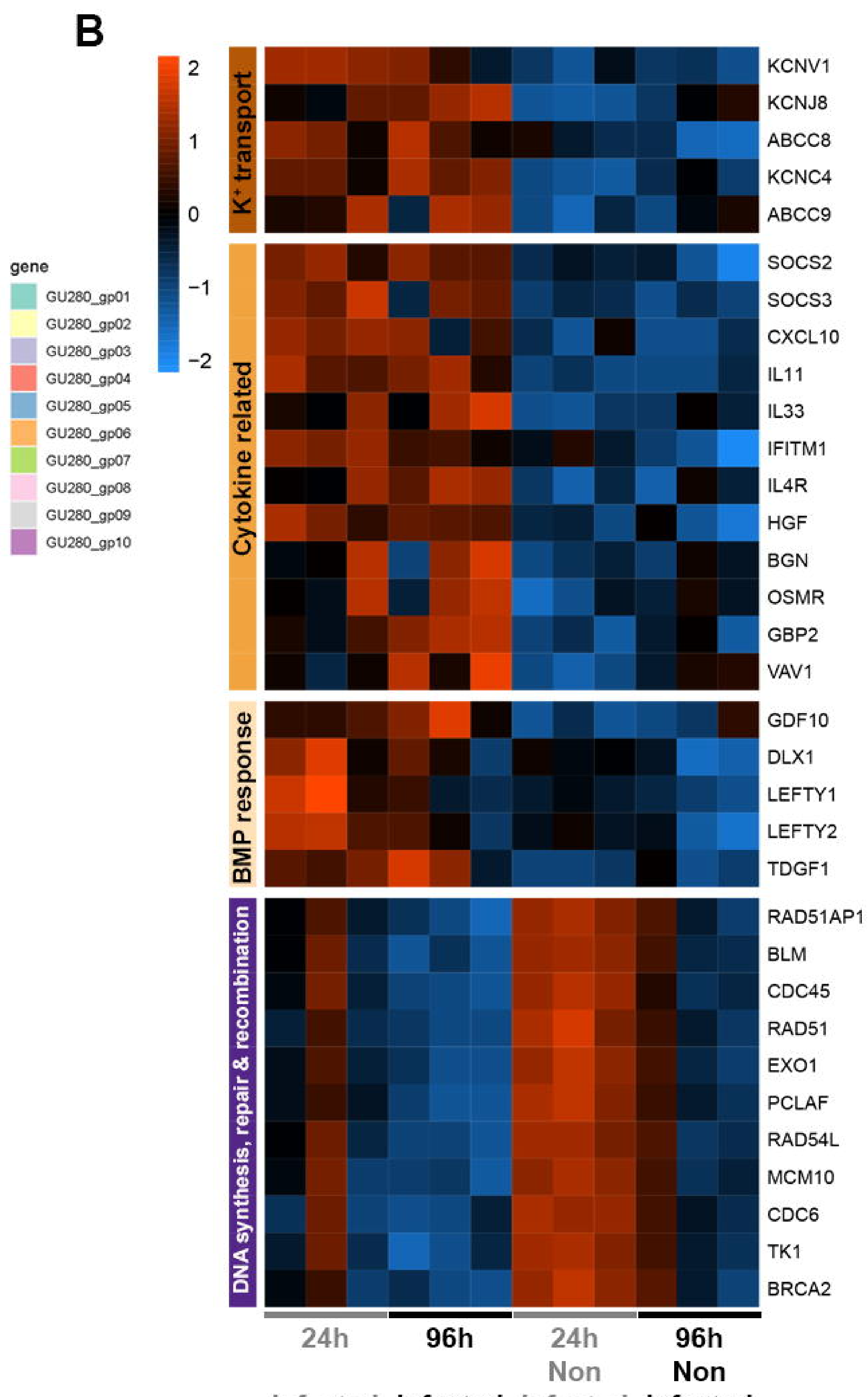

Infected Infected Infected Infected

E

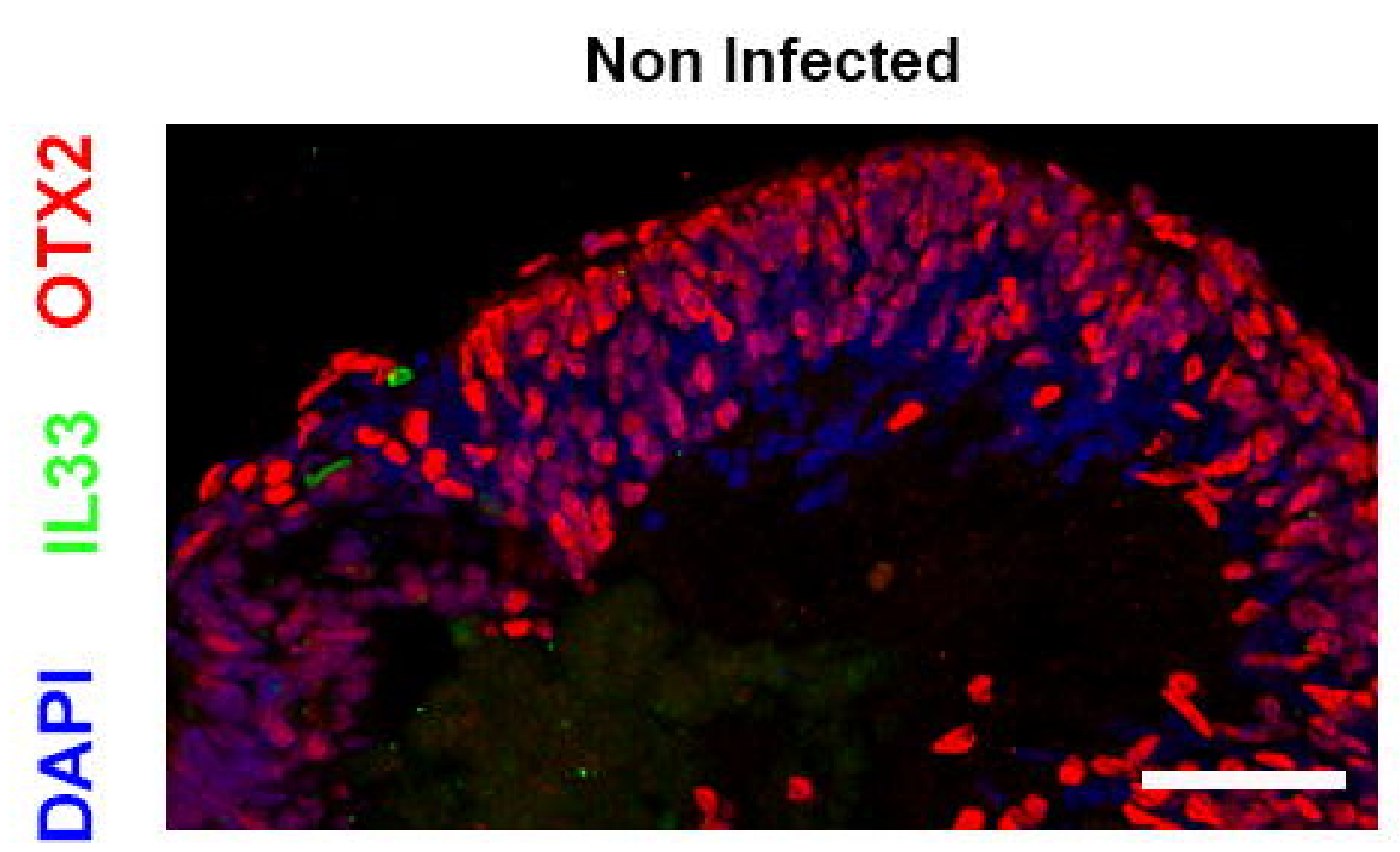

\section{Infected}

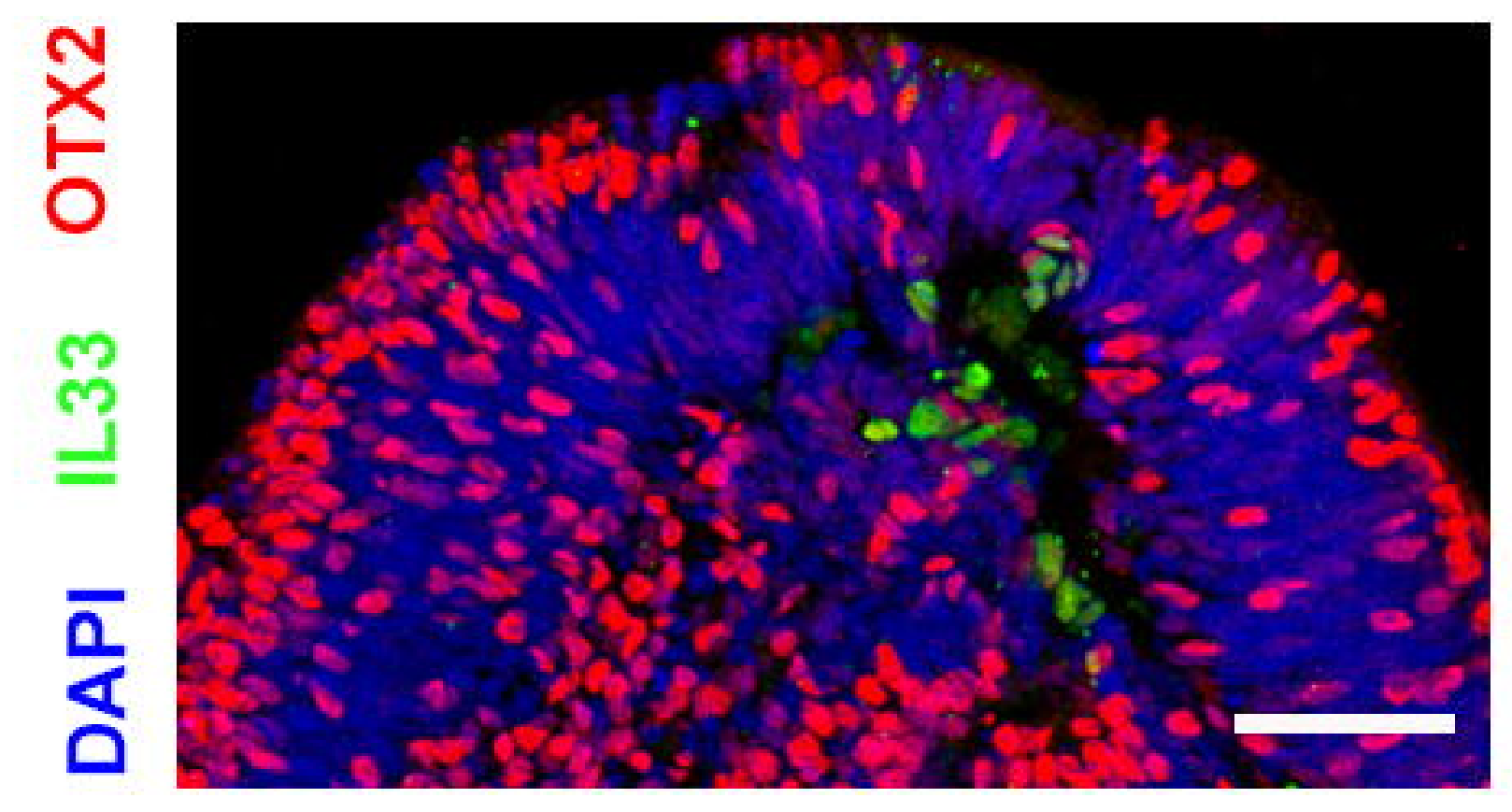

Scale bar $=50 \mu \mathrm{m}$ 
A

Aoat IgG (control)

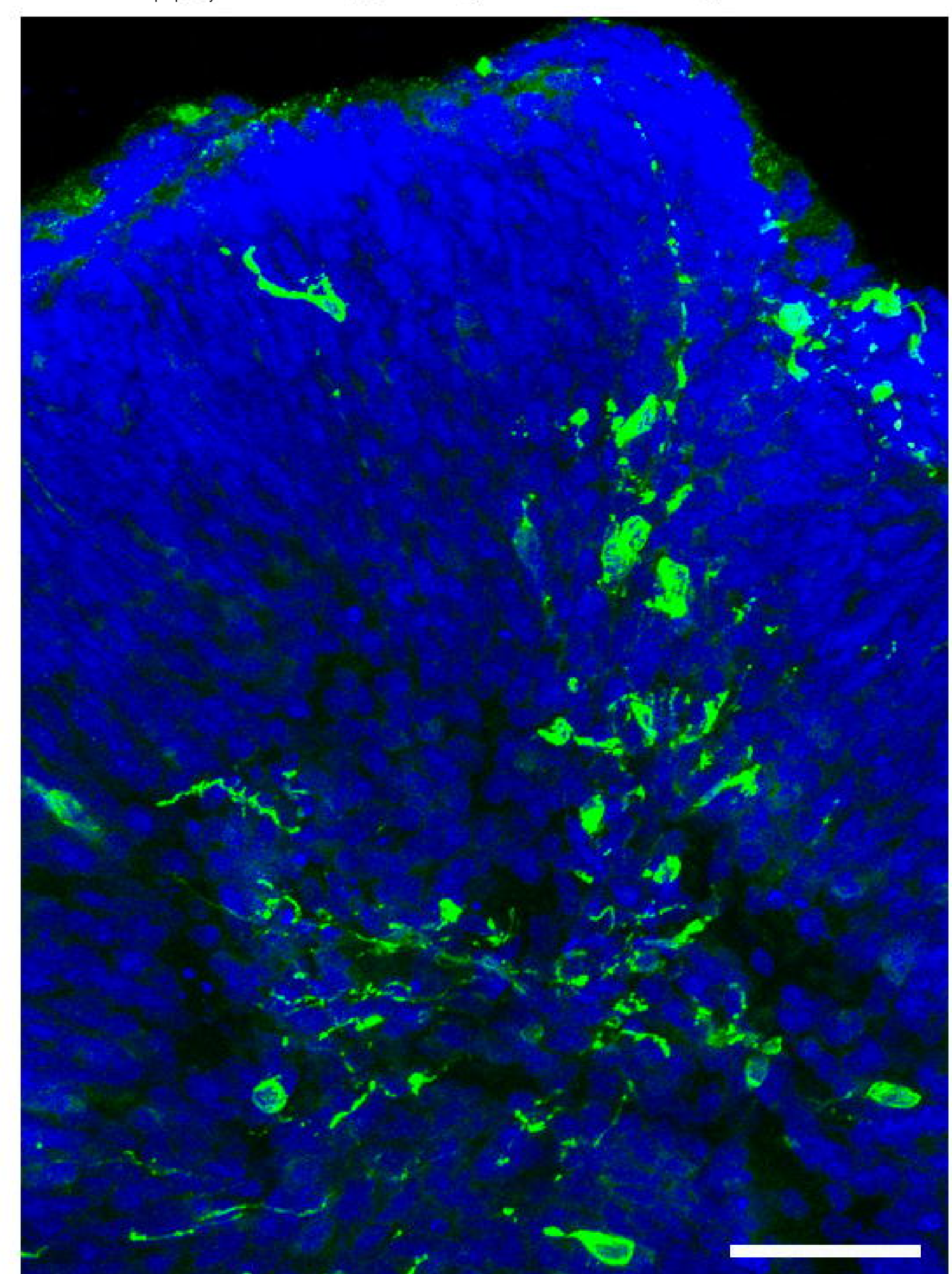

B

goat Anti ACE2 IgG

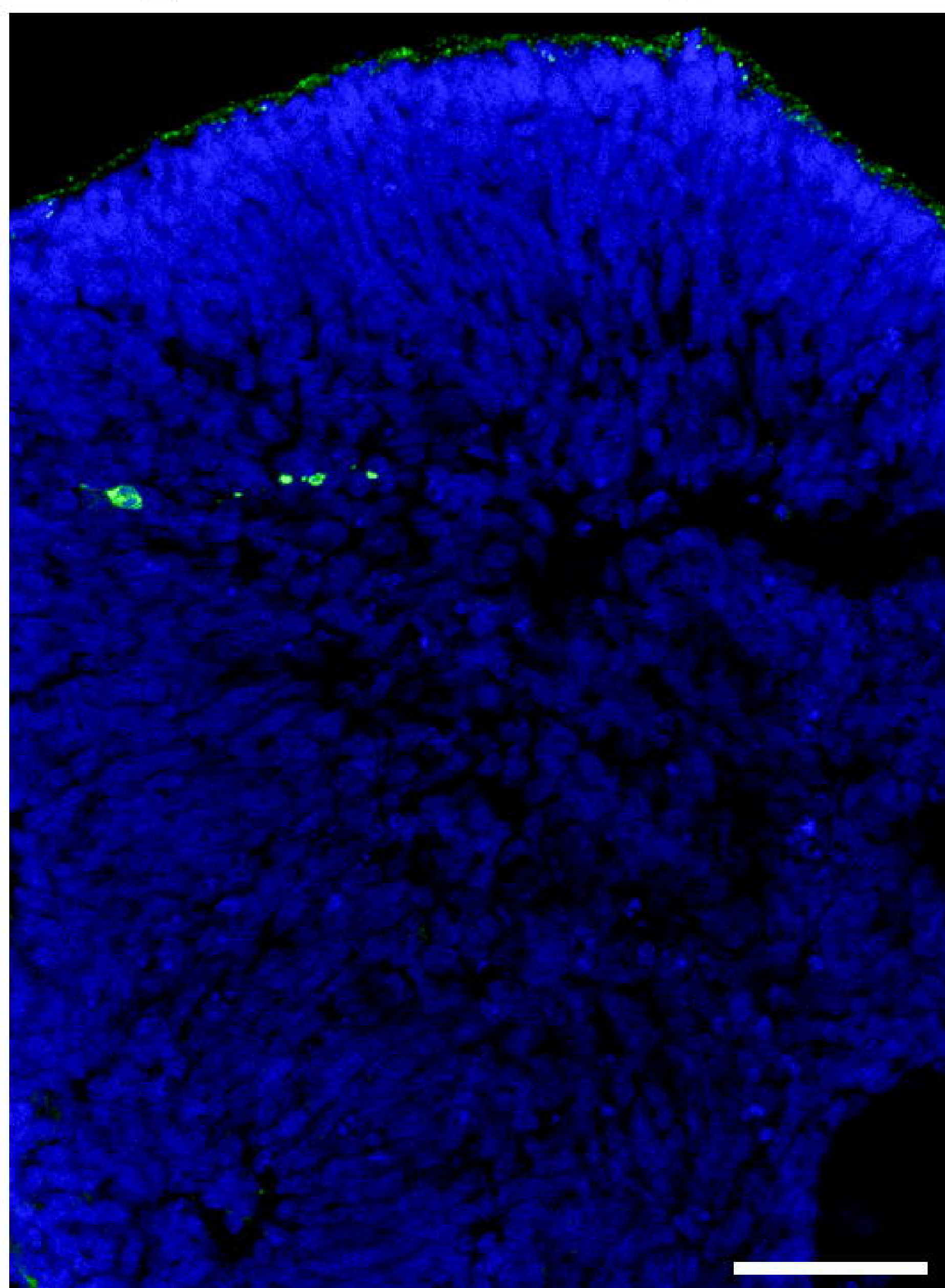

C

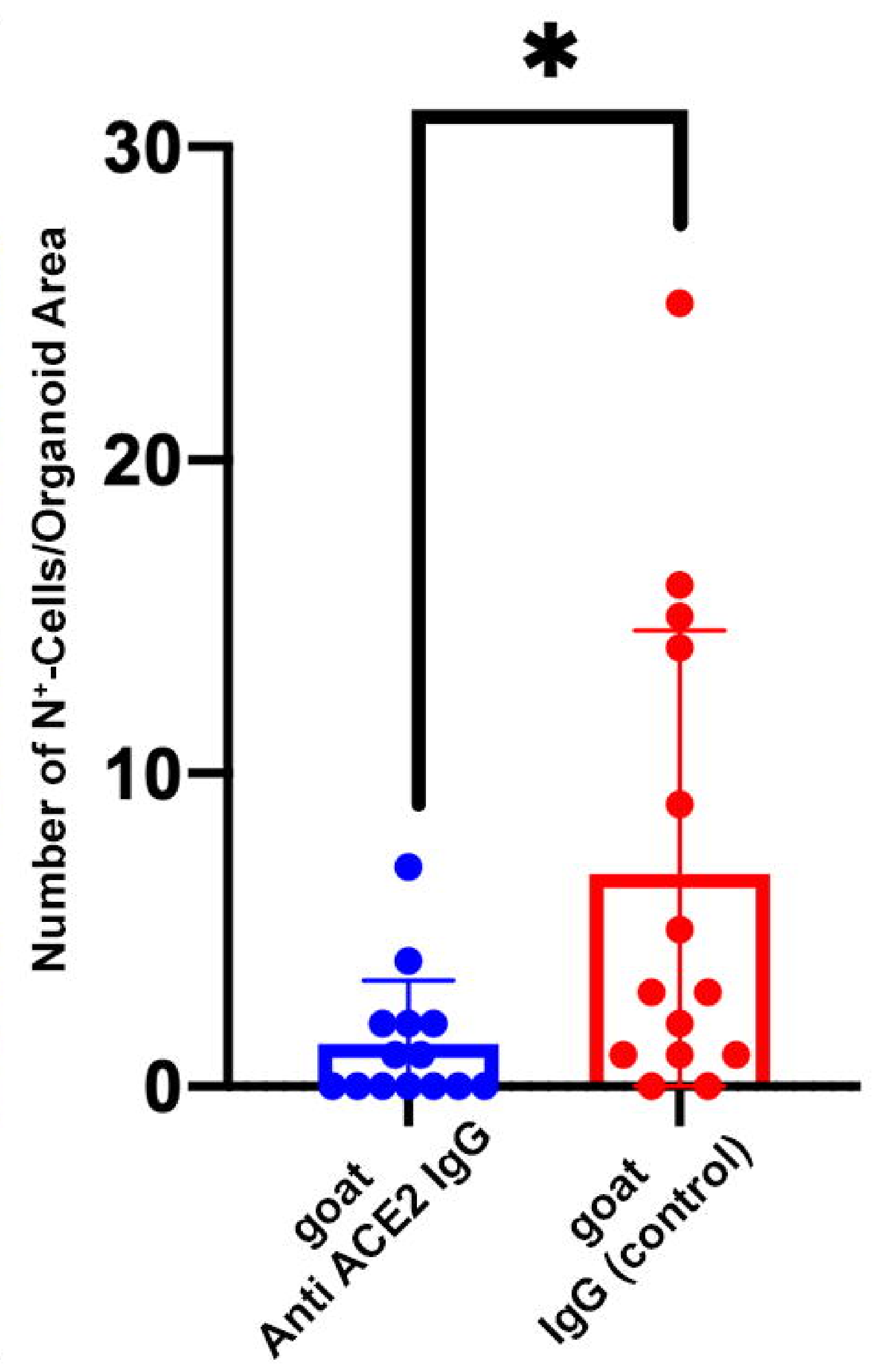




\begin{tabular}{|l|l|l|l|}
\hline & Enriched GO category & P-value & Adjusted P-value \\
\hline \multirow{5}{*}{$\begin{array}{l}\text { Enriched among top } \\
\text { up-regulated genes }\end{array}$} & $\begin{array}{l}\text { potassium ion transport } \\
\text { (GO:0006813) }\end{array}$ & 0.00002763 & 0.01486 \\
\cline { 2 - 4 } & $\begin{array}{l}\text { Gellular response to } \\
\text { cytokine stimulus } \\
\text { (GO:0071345) }\end{array}$ & 0.00007025 & 0.01890 \\
\cline { 2 - 4 } & $\begin{array}{l}\text { cellular response to BMP } \\
\text { stimulus (GO:0071773) }\end{array}$ & 0.0001522 & 0.02730 \\
\cline { 2 - 4 } Enriched among top & $\begin{array}{l}\text { metal ion transport } \\
\text { (GO:0030001) }\end{array}$ & 0.0003060 & 0.02938 \\
\hline $\begin{array}{l}\text { cytokine-mediated } \\
\text { signaling pathway } \\
\text { (GO:0019221) }\end{array}$ & 0.0003120 & 0.02938 \\
\hline genn-regulated & $\begin{array}{l}\text { DNA synthesis involved } \\
\text { in DNA repair } \\
\text { (GO:0000731) }\end{array}$ & $3.688 \mathrm{e}-7$ & 0.0002703 \\
\cline { 2 - 4 } & $\begin{array}{l}\text { strand displacement } \\
\text { (GO:0000732) }\end{array}$ & $9.469 \mathrm{e}-7$ & 0.0003470 \\
\cline { 2 - 4 } & $\begin{array}{l}\text { DNA recombination } \\
\text { (GO:0006310) }\end{array}$ & 0.000002408 & 0.0005882 \\
\cline { 2 - 4 } & $\begin{array}{l}\text { DNA biosynthetic } \\
\text { process (GO:0071897) }\end{array}$ & 0.000007700 & 0.001411 \\
\cline { 2 - 4 } & $\begin{array}{l}\text { DNA metabolic process } \\
\text { (GO:0006259) }\end{array}$ & 0.00001441 & 0.002113 \\
\hline
\end{tabular}




\begin{tabular}{|c|c|c|c|}
\hline & Enriched GO category & P-value & Adjusted P-value \\
\hline \multirow{5}{*}{$\begin{array}{l}\text { Enriched among top } \\
\text { up-regulated genes } \\
\text { shared between } \\
\text { retinal and choroid } \\
\text { plexus organoids }\end{array}$} & $\begin{array}{l}\text { megakaryocyte } \\
\text { differentiation } \\
\text { (GO:0030219) }\end{array}$ & 0.00002439 & 0.003050 \\
\hline & $\begin{array}{l}\text { negative regulation of } \\
\text { pathway-restricted } \\
\text { SMAD protein } \\
\text { phosphorylation } \\
\text { (GO:0060394) }\end{array}$ & 0.00003048 & 0.003050 \\
\hline & $\begin{array}{l}\text { negative regulation of } \\
\text { transmembrane receptor } \\
\text { protein serine/threonine } \\
\text { kinase signaling pathway } \\
\text { (GO:0090101) }\end{array}$ & 0.00003589 & 0.003050 \\
\hline & $\begin{array}{l}\text { positive regulation of } \\
\text { peptidyl-tyrosine } \\
\text { phosphorylation } \\
\text { (GO:0050731) }\end{array}$ & 0.0001218 & 0.007767 \\
\hline & $\begin{array}{l}\text { regulation of cell } \\
\text { proliferation } \\
\text { (GO:0042127) }\end{array}$ & 0.0002921 & 0.01490 \\
\hline \multirow{5}{*}{$\begin{array}{l}\text { Enriched among top } \\
\text { up-regulated genes } \\
\text { not shared between } \\
\text { retinal and choroid } \\
\text { plexus organoids }\end{array}$} & $\begin{array}{l}\text { cellular response to } \\
\text { transforming growth } \\
\text { factor beta stimulus } \\
\text { (GO:0071560) }\end{array}$ & 0.00001530 & 0.009257 \\
\hline & $\begin{array}{l}\text { transforming growth } \\
\text { factor beta receptor } \\
\text { signaling pathway } \\
\text { (GO:0007179) }\end{array}$ & 0.00005211 & 0.01576 \\
\hline & $\begin{array}{l}\text { cellular response to BMP } \\
\text { stimulus (GO:0071773) }\end{array}$ & 0.00009952 & 0.01793 \\
\hline & $\begin{array}{l}\text { transmembrane receptor } \\
\text { protein serine/threonine } \\
\text { kinase signaling pathway } \\
\text { (GO:0007178) }\end{array}$ & 0.0001185 & 0.01793 \\
\hline & $\begin{array}{l}\text { potassium ion transport } \\
\text { (GO:0006813) }\end{array}$ & 0.0003084 & 0.03731 \\
\hline
\end{tabular}

